\title{
Who Needs Sensory Education?
}

\author{
Tanu Biswas ${ }^{1}$
}

Accepted: 3 March 2021 / Published online: 25 March 2021

(c) The Author(s) 2021

\begin{abstract}
Customarily, reflections on the need to educate sensory and bodily enactments with the world, take for granted that it is the child who must be educated. However, the educational passage of becoming 'rational' and 'grown up' often leaves the adult divorced from her own embodied self. As part of my engagement with childism (conf. Wall in Ethics in light of childhood, Georgetown University Press, Washington, 2010; The child as natural phenomenologist. Primal and primary experience in Merleau-Ponty's psychology, Northwestern University Press, Evanston, 2013; Child Geogr, 2019, https://doi.org/10.1080/ 14733285.2019.1668912) in this article, I ask: Who needs sensory education? In response, I propose that it is adults who need sensory education more than their temporal others (Beauvais, in: Spyrou S, Rosen R, Cook DT (eds) Reimagining childhood studies, Bloomsbury Academic, London, pp 57-74 2018) i.e. children. As Merleau-Ponty has shown, the richness of embodied perception that children experience, is relatively distant for adults (Bahler in Child Philos 11:203-221, 2015; Welsh in The child as natural phenomenologist. Primal and primary experience in Merleau-Ponty's psychology, Northwestern University Press, Evanston, 2013). The particular lived-experience I reflect on is the sense of temporality. Accompanied by two distinct, yet interconnected examples of encounters with Baby Ole and Captain Duke, I suggest that being-with-children can enable philosophical clearings for adults to re-cognise plural temporalities, as opposed to a singular clock-time perception of Time. (The preposition with is used in the sense of the Norwegian hos or German bei, whereby an adult intentionally positions herself as a guest in a child's world.)
\end{abstract}

Keywords Childism · Adultism · Overheating · Time $\cdot$ Phenomenology $\cdot$ Reflexive pedagogy

The training of children is a profession, Where we must know how to waste time in order to save it.

Jean Jacques Rousseau, 1762

Tanu Biswas

biswas.tanushree@gmail.com

1 Department of Philosophy, University of Bayreuth, Bayreuth, Germany 


\section{Outset}

Customarily, reflections on the need to educate aesthetic/sensory and bodily enactments with the world take for granted that it is the child who must be educated. However, the educational passage of becoming 'rational' and 'grown up' often leaves the adult divorced from her own embodied self. As part of my engagement with childism ${ }^{1}$ in this article, I ask: Who needs sensory education? In response, I propose that it is adults who need sensory education more than their "temporal others" (Beauvais 2018) i.e. children.

From an adultist perspective the 'child' is invariably understood as an 'entrant' to society. In addition the child is spatio-temporally positioned as a 'pupil' in the schooling sector - a sector which is part of an upscaled and accelerated global economy where Time is equated with Money. As an indispensable part of the global education sector, contemporary schooling culture is structured through highly ordered time-slotting such that sensing Time becomes restrictively associated with the rhythm of external clocks and calendars. In an overheated world characterized by acceleration of acceleration (Eriksen 2001, 2016), such a restrictive temporal ordering is untenable as 'educational'. With respect to the contemporary global challenges (Thunberg 2019; Eriksen 2016), enlightenment assumptions that adults can educate children towards 'better' future states of being are at the very least contentious. With this as my backdrop, I conducted research into the philosophical richness that children have to offer adults (Biswas 2020). In the particular part of my research that I will present, I explored what I could do to re-position myself as a pedagogical addressee in relation to children as temporal others in theory and praxis. Suspending clock-time was an important step for me to re-position myself. I adopted a hybridic phenomenological approach insofar as I realised a form of phenomenological suspension ('bracketing') by drawing upon the Vipassana school of Buddhist meditation as well as including my own breath as a point of return and departure. The greatest difficulty in realising an embodied suspension of clock-time remained the activity of my own intellect which I attempted to curb by relying on logical pluralism as found in Jainism. I will elaborate upon these methodological and theoretical points of departure in a later section.

This article begins with a discussion of the possibility that adults might use their power and capacity to let their interpretations of Time and related self-positioningsbe influenced by children they encounter as research participants or in everyday life their child counterparts. The subsequent section takes its cue from philosophers of education who suggest that in light of the current overheated planetary crisis, it is no longer feasible to hold that

\footnotetext{
1 In scholarly literature the term 'childism' appears in contradictory senses and can be confusing. I use the word in the transformative sense as one finds in Childhood Studies and related fields. Since the early twenty-first century, Childhood Studies scholars reclaimed the positive sense of the term to mean something transformative akin to the way that Women's Studies and Gender Studies used the word feminism (conf. Wall 2010, 2013, 2019). Interestingly the word 'adultism' was used to describe the oppressive influence of adults on children by Patterson Du Bois in 1906. Later, Adam Flasher maintained this usage in his 1978 paper called Adultism. Three years before Flasher, psychiatrist Chester Pierce and Gail Allen published a paper titled Childism and used the term to mean oppression of children i.e. adultism (akin to how we use 'sexism' today). Today one finds the negative use of 'childism' in Educational Sciences and Philosophy too and this continues to confuse scholars and practitioners. One of the reasons that Childhood Studies reclaims the term in a positive, transformative sense is to disassociate the root 'child' from derogatory connotations. One does not use feminism to mean patriarchalism or sexism either! Childism, then, is a way of overcoming adultism. One manner of achieving this in the field of Education is to actively emphasise what children and childhood can teach us. This is my objective here.
} 
adults educate children towards a 'better' future. ${ }^{2}$ I address this from a childist viewpoint, distancing myself from the adultism underlying enlightenment conceptions of education that position the ideal (white, male ${ }^{3}$ ) child as a default addressee of pedagogy. Next, I present a theoretical reflection on two distinct, yet interconnected, experiences with an infant and a toddler from my exploration of the philosophical richness of infants and children (Biswas 2017, 2020). Accompanied by examples of my encounters with Baby Ole and Captain Duke, ${ }^{4}$ I suggest that being-with-children can enable philosophical spaces to open up for adults to re-cognise plural temporalities, as opposed to a singular clock-time perception of Time. Here, the English preposition 'with' is read in the sense of the Norwegian preposition 'hos' or the German preposition 'bei' to designate a sense of being a guest in a host's lifeworld. In doing so, I emphasise that the asymmetrical adult-child relationship renders it impossible to 'be-with' as equals. The closest one can come to 'being-with' is to embrace one's ignorance of children's lifeworlds and partake in them as a guest. Followed by my reflections of the two encounters, I arrive at the that when it comes to aesthetic/sensory education of temporalities I have more to learn from than I have to teach infants and children.

\section{Expanding the Adult Interpretive Agency}

The notion of "temporal otherness" represents a phenomenological understanding of children and childhood that highlights the temporal asymmetry between them and adults (Beauvais 2018). Children do not have access to a past as adults do, while adults do not have access to a future as children do. Symbolically speaking children not only have more Time left to live than adults, but they also inherit past baggage from their adult counterparts. The primary temporal tension of the continuous present is concerned with who is heard in the nowness of lived-experience. There is an imposed degree of fatalism on children insofar as they become agents of a project to which they are committed before they even arrive in the world. Furthermore, they, in turn, might also commit others to similar projects in the future. Temporal tensions are also found in children's resistance to becoming agents of a fatalist project moving towards an unknowable future (ibid.). Beauvais further advocates for a philosophical (here, ethical) balance stemming from the acknowledgement of the temporal otherness of the adult-child relationship (ibid.). However, Beauvais also prevents us from extreme child-centeredness which would condemn adults for oppressing or objectifying children (e.g. Bonnardel 2015; Flascher 1978). Adults experience questions, desires, anxieties etc. as a consequence of children's presence in the world. A balanced approach would entail a curious and compassionate stance towards the adult side of the relationship. Taking such a stance means supporting the adult to open up to the scope of philosophical blossoming that the child's presence offers.

\footnotetext{
2 Also conf. Kohan (2011) who argues that educational philosophy should be understood beyond the logic of 'formation' of childhood.

3 Within the scope of this article I do not further dwell on the intersectional dimensions of what constitutes the imagined ideal child as the default pedagogical addressee. I nevertheless duly acknowledge that adultism is not devoid of intersectional dimensions.

4 Fictitious names used to maintain anonymity. 'Captain Duke' named himself when we played 'Flying Cars in Lava Land' and I retained this play-identity with his consent.
} 
Merleau-Ponty has shown that the richness of embodied perception that children experience is relatively muted for adults (Bahler 2015; Welsh 2013). From the earliest stages of life, the body and the world are experienced as a unity with all the senses working together. Merleau-Ponty's phenomenological holism emphasises that one's thoughts, perceptions, emotions and bodily senses are always informing one another as one engages with the external world. Synaesthetic sensory experiences in this approach are neither compartmentalised nor treated as a 'confusion' of the senses that is to be overcome through the developmental stages that lead to adulthood. The particular lived experiences I reflect on in this article brings the senses into conversation with temporality. I consider aesthetic/sensory learning with respect to the sensing of Time and consequently propose that adults can (re) learn to sense plural temporalities in the presence of children. Some philosophers of childhood have described these temporalities as moving through non-numbered dimensions ${ }^{5}$ of existence and have asserted that children are powerful in this regard (e.g. Kennedy and Kohan 2008).

By 'sensing Time,' I mean both how one feels temporality through the subjective body and how one makes sense of Time through external, objective tools of reference. Measurable Time as singularly ordered through clocks and calendars is an indispensable feature of instrumentally curriculised lifespans passing from school to office. To a large extent, a linear sense of standardised Time is inherited through the strict timetabled life of schooling. Ordering the sense of Time constitutes a necessary part of both the form and content of institutionalised educational processes. Making sense of Time in reference to an external clock streamlines the adult embodied sense of temporalities as singular and linear.

My contention is that such a singular ordering of our sense of Time systematically restricts the adult's capacity to experience and engage with the plural nature of temporality. In turn, I regard this as the sensory poverty of adulthood, but it is something which can be overcome in the presence of children. The practise of consciously suspending the natural attitude of grasping clock-time as real Time while playing with children could offer adults counterparts an aesthetic clearing to sense Time in its subjective plurality. 'Playing' in the framework of the following reflection is not an activity restricted to childhood, although there is much that adults can learn from the specific play of children. Childism, however, employs the term 'play' in a broader ontological light.

From a childist perspective, playing and philosophising are synonymous because both refer to the interpretive agency of humans regardless of age. Hence, playing is philosophising and philosophising is playing. An integral aspect of a childist understanding is that playing/philosophising belongs to the ontological structure of what it means to be human (Wall 2013). This means that playing/philosophising is both something a human does and something a human is. Regardless of age, one is constantly playing with what it means to be-in-the world; for example, by playing out one's social roles as one interprets them. Being-in-the-world requires constantly interpreting (and thereof positioning) one's self in relation to other selves and objects. In other words, one does not simply sense the world, one continuously makes sense of the world: i.e. one constantly posits some value to other selves and objects. In light of power differences between adults and children, adult interpretations and self-positionings influence how and to what extent the child may position herself. ${ }^{6}$

\footnotetext{
${ }^{5}$ Like the mathematisation of Time through measuring devices like clocks.

6 I use the word 'position' to simultaneously mean both physical and mental placing. Further, the word 'mental' does not exclude 'emotional' as has been traditionally been in the case in referring to sensations that occur solely in the physical area called brain as in the Cartesian mind-body divide.
} 
At the same time, the adult also has the power to let her interpretations and self-positionings be influenced by her child counterparts. The second possibility is there because children enable newness in terms of how one could make sense of the world. As MerleauPonty writes, "In the home into which a child is born, all objects change their significance; they begin to await some as yet indeterminate treatment at his hands; another and different person is there, a new personal history, short or long, has just been initiated, another account has been opened." (Merleau-Ponty in Welsh 2013: 21). External objective tools of reference such as clocks that are employed to make sense of Time also change their significance in the presence of a child. The child's presence widens the scope for the adult to exercise her interpretive agency in terms of grasping Time. In turn, offering the adult counterpart an aesthetic clearing to sense Time in its subjective plurality. While consciously suspending the natural attitude of grasping clock-time as real Time seems to be an indispensable prerequisite for this clearing, rigid adultist positions remain a challenge.

\section{‘Child': More than a Default Addressee of Pedagogy}

Philosophers of education like Straume (2019) and Su and Su (2019) have argued that the assumption that adults educate children towards a 'better' future no longer holds in light of contemporary planetary challenges (conf. Thunberg 2019; IPCC 2018; Eriksen 2016). Consequently, this implies that adults may and should also be seen as pedagogical addressees in relation to children. A major philosophical as well as practical obstacle to making this shift is that the concept 'child' has a long history of being metaphorically deployed as the model for human progress (Duane 2013:3; Wall 2019). For instance, the influential enlightenment philosopher Kant outlined the telos of education as the development of humanity insofar as 'man' had to be disciplined, cultured, civilized and moralized through education (Kant 1904: 121-123; Schapiro 2003). In such views both instinct and inclination are associated with primitive states to be conquered by reason found in 'civilized' states (ibid.). Traditional interest in studying childhood orients itself towards regarding the child as raw material for cultural learning. This viewpoint refers to adult members of the society as 'agents' of socialisation insofar as they become models for the child's behaviour (Speier 1976: 169).

Distancing itself from this vein of pedagogical power dynamics, a childist lens seeks to explore how a child may also be allowed to be an agent of (re)socialisation for an adult. For this purpose, it is helpful to start by considering why the 'primitive' and 'sensitive' have long been understood in linear hierarchical opposition to the 'developed' and 'sensible'. Bøyum (2002: 100-101) deconstructs the adultist interpretations found in, for example, Kantian educational philosophy and re-interprets the childlike in a transformative childist sense. Predominant positions, such as those found in Kant, equate the natural, emotional, subjective and instantaneous qualities that children embody with irresponsibility. From a childist standpoint the 'childlike' is rather understood as free because it is not determined by social conventions to the extent found in adults. Through this standpoint, the subjective is valued for its capacity to experience life in the now. Moreover, the organic childlike way of existing does not draw distinctions like the analytical approach demands. Finally, fantasy governs logic and so the childlike is associated with play.

Similarly, Merleau-Ponty's holistic phenomenological attitude towards childhood does not engage in a hierarchical compartmentalisation of sensitivity and sensibility. Instead he observes a harmonious consistency between the sensitive and the sensible, by 
emphasizing that processes such as sensory perception, thinking and emotions inform one another while the self engages with the external world. The child does not first reflect on her body and then encounter the world. Rather, both the body and the world are a fundamental unity. Such a stance towards the world continues through adulthood. It is not as though an infant questions whether the face of the other is human and hence proceeds to imitate facial gestures. The capacity for imitation and playful response is in motion even before an infant begins to recognise herself in a mirror. Processes such as thinking are always extending into an intersubjective world through the body.

The body is the embodied self marked by behaviours, interests and values of those around it before a conscious reflection on the 'I' sets itself into motion. The embodied self of a child nevertheless actively partakes in self-constitution i.e. it is not totally hemmed by external social upbringing. From the earliest stages of infancy, MerleauPonty observes a capacity to be interested in and respond to others. Thus, even in those first adult-child interactions intersubjectivity is understood as a process of creative reciprocity which continuously expands, overlaps, and evolves throughout the lifespan. The lifespan is viewed as an endless play of trying on new roles, appropriating various ways of being observed in others and performing those roles from diverse vantage points.

Consequently, regardless of age, encounters with others are originarily positive insofar as they offer the scope for both a creative reciprocity and a playful expansion of the horizons of being an embodied self in the world. From this point of view, both the adult and the child may experience each other as teachers who reveal alternative ways of sensing and being in the world (Bahler 2015; Welsh 2013). While the emphasis on the fundamental unity of the sensitive and sensible is particularly important for sharpening the childist lens in theory, in practise there are barricades to be overcome. Here, I refer in particular to the barricades that deter adult capacity of suspending the natural attitude of singular clock-time as real Time. The wish to engage with children as counterparts who are more than default addressees of pedagogy, is not enough to actually arrive at doing it. When the 'irrational' child is reduced to the one who must learn a specific singular temporal rhythm, the 'rational' adult is simultaneously reduced to the one who must teach it. While this may put the adult in a powerful place, it also curbs the capacity for the adult to engage in a creatively reciprocal expansion of playing with what it means to be a temporal self in this world.

In highly industrialised societies, the dominant way of life for a child entails becoming socialized by spending a sizable amount of time being spacio-temporarily positioned as pupils in schools. Schooling provides the child access to the formal education necessary to eventually integrate into a future adult market. It orders the temporal passage from child to adult status, whilst restricting the ways in which the child can spend her time (James et al. 1998:41). Such structural positioning administers a singular possibility for managing and controlling child populations (ibid.). Daily time-slotting through lessons, break-time, etc. is key to the way modern schooling orders the child's temporal passage (Oswell 2013: 121). Restrictive ordering of the temporal passage on a daily basis, implies that one learns to sense Time through the rhythms of external clocks and calendars.

Seen as part of the modern history of overheated acceleration and an upscaled standardisation of Time (Eriksen 2001, 2016), childhood becomes a highly timetabled event (Ennew 1994; Beauvais 2018). Time and Money become tightly coupled in industrial society wherein the clock is used to promote synchronised efficiency in steadily upscaled settings (Eriksen 2001: 53; Ennew 1994). Consequently, childhood is filled with highly organised activities within a highly instrumental global education sector. 
No matter that the child's learned response to the circadian rhythm is biological, the cultural order of sleeping and waking (increasingly responsive in modern societies to the rhythms of the workplace, transport system, the child care system and the broadcasting system) imposes another socially 'real' set of rhythms. (Ennew 1994:127)

The scope for exploring various temporalities that can be experienced outside the socially 'real' set of rhythms, is systematically restricted and singularly channelled for the child.

As an 'agent of socialisation,' the adult unfortunately also loses access to experiencing temporalities outside the singular temporal rhythm and, in turn, is restricted from experiencing the child as a teacher who may also introduce her to other ways of tempora(ri) ly being in the world. In other words, the 'irrational' child is reduced to the one who must learn a specific temporal rhythm and correspondingly the 'rational' adult is reduced to the one who must teach it.

Particularly with regard to sensing Time, adults can learn to sense multiple temporalities in the presence of their temporal others, i.e. children. While the socially 'real' temporal rhythm of an external clock is one way of experiencing temporal experience, the not-yet ordered sensing of Time in childhood is closer to diverse temporalities than in adulthood whereby socially 'real' Time is taken for granted as the predominant way of sensing and being in the world. Opening up to the scope of creative reciprocity that the adult could have in encountering her temporal other as a teacher could be a way to overcome the sensory poverty that comes with having over-appropriated the clock-sense of Time.

The sovereignty of embodied, functional, chronological time, that I call 'clock-time', has to be actively suspended by adults so that the possibility of a temporal creative reciprocity with children may open up. The significance of challenging the sovereignty of linear, chronological time prevalent in educational theory and praxis is a shared preoccupation for the intertwined fields of philosophy of childhood and philosophy of education (e.g. Kohan 2014; Tesar 2016; Murris and Kohan 2020). This has lead especially philosophers of childhood to at times adopt non-chronological forms of argumentation and re-script how processes of pedagogical philosophising themselves might unfold (e.g. Kennedy and Kohan 2008). My conceptual dichotomy between 'real-' and 'clock-' time has the restorative role here of knowing what has to be overcome to allow room for creative reciprocity. It is a heuristic device and does not describe two opposing kinds of Time.

Given the asymmetry of the adult-child relation, allowing room for creative reciprocity can only be taken by the adult. In other words, children cannot teach something if adults don't let them. Letting the child teach does not imply that the child plays the role of an adult teacher. Rather, it implies accepting the opportunity to broaden the horizons of how an adult could exercise her interpretive agency in the presence of a child. A childist lens calls for approaching the 'natural, emotional, free, subjective and organic' state of being (Bøyum 2002) as a clearing to relax the stiff, ordered, conceptual muscles of the adult embodied state. Nevertheless, it necessitates the arduous task of beginning a conceptual shift that allows one to see the child as more than a default addressee of pedagogy. I propose that an indispensable component of making this shift is suspending the natural adult attitude towards seeing singular, linear clock-time as real time. The possibility of creative reciprocity, in terms of learning with (hos/bei) children could then unfold. For an adult, this is no child's play (pun intended).

In the following section, I present a reflective description through a continuum of two experiences in order to illustrate my endeavour to explore the scope for how adults can blossom philosophically with (hos/bei) children. Through these reflections I unravel the sensory treasure that was lurking beyond my adultist attachment to external clock-time. 


\section{Reflections with a Continuum of Two Experiences}

Baby Ole and Captain Duke were two child citizens of the Norwegian fjord city of Trondheim, who supported me in exploring the scope of philosophical blossoming for adults when they enter children's playfully constructed worlds as guests (Author 2020). The use of fictitious names is first and foremost to protect identities. Captain Duke created his own character as part of playing 'Flying Cars in Lava Land' - an imaginatively constructed world that he self-authored. I chose to refer to him by the name he created for himself because it is deeply intertwined with the experiential context that I present later on in this section.

While there were other children who were co-explorers on my journey, I have chosen two distinct experiences with Baby Ole and Captain Duke because of the specific role the suspension of clock-time played in our encounters. Both examples however differ insofar as the first one involves an infant and the second one a toddler. Secondly, the experience with Baby Ole was an informal precursor to my encounters with Captain Duke, which were more formalised and theoretically pre-deliberated. Consequently, readers will find a variation in the manner in which the reflections are presented. The account of the encounter with Captain Duke for instance begins with a brief orientation of the hybridic phenomenological approach I used in order to enter into an immersive play encounter lead by him. The inclusion of the breath, based on the Vipassana school of Buddhist meditation, along with Jaina logic as my analytic framework during the encounter were deliberate choices influenced to a large extent by what I learnt from being with Baby Ole. One could well say that Baby Ole in his own way helped to prepare me to meet Captain Duke as a toddler. Thus, the following accounts are to be read as a continuum of two experiences that contribute to a reflexive process of thinking about sensing Time.

\section{Encountering Breath with Baby Ole}

In 2012, when I lived in the city of Trondheim, I was closely befriended by a couple awaiting their first born. On Baby Ole's arrival, I began helping his guardians in care-giving and had the possibilities of getting to know him closely as an infant. The ways in which Baby Ole showed signs of sensing the world around him captivated me. As I took care of him, taken-for-granted motions of my mundane human condition.g. breathing, sleeping, waking - as ways of sensing spatio-temporality through my body surfaced. The most striking of all was coming closer to a subtler and and more diverse sense of temporality. Baby Ole did not share a sense of mathematized clock and calendar time that human beings begin to regard as real Time once they are socialized into being grown-up. ${ }^{7}$ However, universal social ordering of Time through clocks is possible because there are temporalities in the first place (Lippitz 1983). By way of analogy one may say that it is possible to set order into rivers through engineering because water flows in the first place.

In the presence of Baby Ole, Time did not tick away to the rhythm of the clock. Baby Ole's time-less, ${ }^{8}$ temporal scale often conflicted with those of adults like me around him. I

\footnotetext{
7 The term grown-up here refers to the adultist sense of the term as I have presented earlier in this text. It does not refer to Biesta's use of the term implying 'a way of being' (Biesta et al. 2019), which according to critics like Cassidy (2017) appropriates and reinforces adultist connotations.

8 In the sense of clock-time.
} 
supported mediating his 'erratic' flows of sleeping and waking into timely cycles through a synaesthetic approach bringing together sight, sound, touch and movement. For instance, entering his perceived spatial field, making melodic sounds, touching gently or moving around holding him firm and close to the body helped tune his cycles into our clock-time. Additionally, placing a little piece of soft red wool in his palm, or keeping it within his convenient reach was an indispensable part of Baby Ole's timely sleeping and waking initiation. Such 'rituals' gradually initiated him to start tuning into the clock we followed.

In terms of visual attention or making and maintaining eye contact, Baby Ole showed an impressive capacity to maintain a constancy of attention. When placed in an eating-chair, it often seemed like he was 'distracted' from the bowl of food. But then he would hold my gaze and smile playfully. If my own attention moved to another object in the room, he followed my gaze. On some occasions I noticed that Baby Ole's capacity to hold our mutual gaze was greater than most adults I knew, who would easily look away or avoid eye contact much more quickly. Baby Ole seemed to have a considerable capacity to look. I would let myself be guided by him by looking where he looked. Consequently, I could start relating to the immense joy he took in the smallest things. Similarly, I began listening more carefully to 'meaningless' sounds that captured his attention. Baby Ole used eye contact and babbling to maintain connection with me if I allowed my attention to wander away and to engage me in activities that he invent e.g. him throwing the spoon and me fetching it.

Once, Baby Ole and I were in a recreational room for children and their caregivers at the university student village. According to the agreed schedule, the hours should have been spent playing and socialising with other children within Baby Ole's age-group. However, Baby Ole seemed reluctant to join the activities. He crawled away every time I encouraged him towards other children or directed his attention towards toys. He maintained eye contact with me initially, made sounds and flashed me with notorious smiles as he crawled away or resisted me carrying him to spaces that he did not want to go to Gradually, he stopped maintaining eye contact or addressing me with sounds and got cranky. I found myself co-responding to his signs of resistance by feeling restless and irritable myself. Baby Ole couldn't understand my imposed importance of socialising with other children during the clock hour when it was planned.

Eventually, I let him crawl in the direction he chose i.e. away from the designated play area. I walked towards a reclining chair in the same area and took a seat. I waited clueless as the clock ticked and Baby Ole explored 'nothing' in the corner. Finally, he crawled towards me and reached out for my knee and I lifted him onto my lap. We stared at each other. He then neared my chest and I could feel the difference in the rhythm of our respective breaths. Compared to mine, Baby Ole's breath was far gentler and subtler. I began tuning into his breath and I stopped focusing on the clock-time emphasised in my mind. As our breathing rhythms came closer together, Baby Ole began closing his eyes and fell asleep. I remained tuned into his breathing tempo which in turn was transforming my sense of temporality. There was a gentle stillness, my eyes open and aware of my surrounding world, yet I also felt removed. It was as if my body were a breathing mattress with my hands placed on Baby Ole's head and back.

Revisiting the rich moments with Baby Ole through Merleau Ponty's phenomenological holism offers an interpretive paradigm which allows me to view Baby Ole as having taught me something about sensing Time through the way I breathe. Despite their interdependence, temporal registers scales of adult and child beings often clash. Tuning into moments of harmonious intergenerational temporality with Baby Ole required disempowering my own clock-timed temporality and opening up to a new way of negotiating embodied temporalities. The primary negotiation between child and adult seems to begin with the embodied 
negotiation of Time itself. Who plays along with whose sense of 'real' Time seems to be the beginning of an embodied philosophical tension between two temporal kinds of beings called child and adult. At the same time, following Merleau Ponty, the scope for creative reciprocity lies in the originary positive nature of this relating.

It is impossible to access what went on in Baby Ole's inner consciousness. However, what can be said about the realm of internal consciousness i.e. the realm of thoughts, feelings, plans and so on is that it is in motion since even before 'nonsensical' babbling begins. Internal consciousness is where our subjective temporalities mediate our relationships with the external world. Subjective temporalities are largely mediated through counterfactuals expressed through words like might, should, could, would and if. Even babies consider possibilities, distinguish them from reality and use the knowledge to alter the world around them. They do sense that there are rules in the external world, but the rules can be negotiated and changed (see Gopnik 2009). Adults certainly have larger physical, social and temporal compared to children and infants. However, the European enlightenment's conclusion that childhood is a primitive state in need of development by the adult does not follow.

From a holistic phenomenological standpoint a stage-based developmental hierarchy is untenable. Even developmental psychology now begins to recognise that children and adults have different yet equally complex and powerful minds, brains, and forms of consciousness serving diverse evolutionary functions that cannot be captured with a chronological clock-time logic underlying a stage-based developmental hierarchy (Gopnik 2009). They are regarded as different forms of homo sapiens (ibid.). Accordingly, unlike in the traditional understanding of stage-based development as simple growth, development is better grasped as consisting of processes of metamorphosis, for instance like the case of caterpillars becoming butterflies. In the case of humans it seems more as though adults are "the vibrant, wandering butterflies who transform into caterpillars inching along the grown-up path (Gopnik 2009: 9)."

As a caterpillar (to use Gopnik's metaphor), my experience of knowing Baby Ole closely had not only made me aware of the centrality of breathing in tuning into the lightness of temporal otherness; it had also hinted towards playfulness in the ontological structure of how we exist as bodies in the world. The sensory richness that I had observed in Baby Ole allowed me in turn to confront my own sensory poverty and left a significant trace in me. It further informed the direction of my inquiry; that significant trace surfaced organically in my exploration of the scope for philosophical blossoming for adults when they play with (hos/bei) children (Author 2020 in press). The trace was a trace of awareness that there was something beyond my sense of Time which was ordered according to the clock. I owed the ordering of my sense of Time to past processes of socialisation of which institutional schooling was a large part. Timetables and schedules were an essential feature of capturing, measuring, using, spending or wasting 'Time'.

Learning to move my body in accordance with the rhythm of an external clock as opposed to internal sensations was an important marker of being seen as a grown-up. Consequently, clocks and calendars had become a naturalised reference for me to grasp Time, in turn restricting the repertoire of possible experiences of Time beyond the adult-sized clock. When I met Captain Duke as a toddler who generously let me enter his playfully constructed world as part of my research, ${ }^{9}$ I took with me an important lesson I had learnt with Baby Ole. The first one was that my breath would serve as a point of departure and

\footnotetext{
9 Captain Duke's family and I had gotten to know each other prior to the research encounters. I had served the family shortly as a babysitter and was therefore familiar to Captain Duke.
} 
return whilst tuning into the temporality of the other. Further, this experience with Baby Ole also influenced my deliberate decision of suspending clock-time while interacting with Captain Duke.

\section{Unstiffening Conceptual Muscles with Captain Duke}

To begin briefly with a relevant digression: encountering Captain Duke for playfully immersive experiencees required a systematic preparation because I couldn't immerse myself in the imaginatively constructed worlds as effortlessly as he did. This included incorporating theoretical considerations from outside the continental phenomenological tradition, that is, the Jaina school of pluralistic logic, and pragmatic tools such as the practise of returning to the breath from the Vipassana school of Buddhist meditation. The play encounters had a temporality of their own and did not always meet the clock-schedules that Captain Duke's adult caregivers and I agreed upon. In order to tune into Captain Duke's specific temporalities beyond the pre-determined schedule of my visit, the first suspension I made was the suspension of external clock-time. The second suspension was a spatial suspension of my taken-for-granted world, that is the network of meanings around me, which usually enable me to make sense of everyday life. The reflective account that follows describes approximately 6 clock-time minutes of an intense play encounter in 'Lava Land' (Biswas 2017, 2020). Due to their intensity those 6 clock-time minutes felt indescribably longer. With my embodied experience as the focal unit of analysis, I describe the encounter with Captain Duke in a 'kitchen'.

In the 'kitchen', Captain Duke repeatedly flew a toy car as though it were a plane that he was holding in his hand. At first, these repetitive cycles felt boring because they did not make sense. But I consciously returned to my breath and intellectually opened to the meanings Captain Duke brought to life through his dynamic embodied movement. Gradually, it ceased to appear boring and senseless. Rather, an exciting and abundantly meaningful alterity entered the horizon of my perception. Captain Duke flew the toy car over the kitchen counters and landed it on the dining table. His movements were accompanied by onomatopoeic sounds he generated through his body. When I stepped outside the 'route' he cautioned me that there was lava on the floor and that all the cars were in it. Therefore, we had to fly the cars and land them on the dining table. As he continued to fly the cars on the route, I gradually surrendered to his lead and followed.

The presence of Captain Duke's adult caregiver in the room made me conscious of my own adulthood, but I played along with Captain Duke. Somehow I was simultaneously observing and immersing myself in the play. I managed this by surrendering to Captain Duke's lead as much as possible until at one point our body movements synchronised. In other words, I copied Captain Duke's moves. When I couldn't sustain the synchronicity, Captain Duke repeatedly explained to me what I should change or do better until I got into a flow again. Eventually, my prior conceptual understanding of the network of meanings - that is, (of) the world around me - remained and at the same time ceased to exist. As opposed to the usual sense within which I encountered them, material objects such as the 'dining table' revealed themselves as co-determinants of our bodily movements.

Subsequently, my prior conceptual understanding relaxed and a parallel world presented itself to me. Captain Duke accompanied me through an embodied thought experiment in motion and helped me see what else a particular spatio-temporality could be. This, in turn, opened up horizons for me to unstiffen my conceptual muscles. I could somehow experience being and not being in the kitchen at the same time. The experience is further 
characterised by its indescribability and I was compelled to acknowledge that I usually capture experience through my linguistic repertoire. Furthermore, since I am not aware of everything, not all concepts through which I make sense of my world as a network of meanings are exhausted. However, in being present with Captain Duke there were plenty of opportunities that lit up which were within the scope of my awareness and self-reflection. These opportunities called for relaxing mental muscles in a way that can facilitate crossing the borders of my taken-for-granted world. Subsequently, I could experience other fleeting, temporal, co-existing worlds regardless of their contradictory appearance. I name such opportunities philosophical clearings.

In life, objects within the scope of my awareness make sense within a network of meanings that I take to be true. The dining table appears as a piece of furniture to sit at, not to sit on. Similarly, the kitchen counter is to prepare food which in turn is placed on the dining table. Utensils, appliances and so on as well as empty spaces in between the kitchen counter and the dining table assume meaning in functional relation to each other. Networks of meanings extend to upscaled macro and physically absent aspects of my world too (see Heidegger 1972, 1977, 2010). The dining table probably came from an IKEA store. It was brought to IKEA from a factory in a distant nation, which in turn procured raw materials such as wood from trees in a forest from another nation. Furthermore, there are co-responding 'professions' and codes of transaction of resources in where the acts necessary to maintain dining table production are systematically carried out by human beings and other species, and so on. This is one way the kitchenness of a kitchen that I take for granted as real is maintained. With Captain Duke, my natural attitude of taking this kitchenness of a kitchen for granted was put into question. I was in a land of lava, where I flew cars in order to rescue them. As a consequence, within the frame of that other spatio-temporality, the distinction between cars as play-world things or toys and the kitchen as a real-world thing became bleak. The kitchen remained a kitchen and at the same time became a play-world thing, just as the play-world things remained play-world things and simultaneously became real-world things. In flying cars, with my body making accompanying onomatopoeic sounds like Captain Duke, my body was not only a doer of kitchen-world acts, instead it was also the doer of lava-land acts (Author 2017; Author 2020).

Suspending my natural attitude of clock-time as real Time was a necessary step for me to be able to experience myself in co-existing spacio-temporalities.

\section{Outro: Who Needs Sensory Education?}

As an adult, it seems like one has both the capacity and the power to suspend one's natural attitude of clock-time as real Time; to play/philosophise with what it means to exist as temporal beings. The same applies to the capacity and the power to tune into breathing in relation with a child. Why then did I need to deliberately theorise and attempt an hybridic phenomenological approach in order to become 'a doer of lava-land acts' with (hos/bei) Captain Duke? Wasn't my having learned about the centrality of suspending clock-time as real Time with (hos/bei) Baby Ole sufficient? The response unfortunately is no, because the structures within which I learned to exercise agency to interpret and perform the most mundane physical acts stiffen me and my conceptual muscles.

As I have written earlier, accelerated acceleration and an upscaled standardisation of Time (Eriksen 2001, 2016) render modern childhood into a highly time-tabled event (Ennew 1994; Beauvais 2018). Educational institutions, such as schools and 
kindergartens, are sites where timetabled life is ordered and streamlined to serve highly industrialised societies (Oswell 2013; James et al. 1998). The tight industrial coupling of clock-time with the financial dimensions of synchronised efficiency also orders children's Time (as default addressees of pedagogy). As Ennew has written, the cultural order of sleeping and waking (and with it breathing) is increasingly tuned to rhythms of the workplace, transport system, child-care system and broadcasting system which, in turn, impose a socially 'real' set of rhythms onto children (Ennew 1994: 127; brackets by author). Those who are structurally positioned as agents of socialisation (e.g. teachers in institutions) are caught up in exercising their agency to maintain the standardised temporal rhythm. In the practise of teaching, the scope of being open to learn by tuning into the child and the sensory wealth that this can bring is blocked. The practise of teaching becomes instead about constantly re-learning the singular temporal order necessary to maintain and teach industrial efficacy. Tuning into alternative temporal rhythms and letting the child teach is a matter of choosing to exercise one's interpretive agency to begin to undo industrial efficacy.

With the account of my experience with Baby Ole, I began with how I was captivated and eventually became increasingly aware of fundamental taken-for-granted motions such as breathing, sleeping, walking and so on. Spatio-temporality was sensed through my body in contact with the external world. As part of Baby Ole's adult team of caregivers, I participated in ordering his spatio-temporality through rituals tuned to the clock we followed. At the same time, being captivated, or rather letting myself remain captivated, gave way to noticing 'little' capacities that Baby Ole had, such as his capacity to look and to listen. As a result, the seemingly mundane and meaningless could become temporarily meaningful and relatable to me. The encounter I highlighted with Baby Ole was the temporal alterity I sensed by way of co-responding and tuning into his breathing rhythm as closely as possible. The central lesson here was that I had to exit clock-time in order to tune into my temporal other. Our temporal scales often clashed as I was usually occupied with his ritualistic initiation into clock-time rhythms.

Exiting the clock-time sense of temporality implied little ontological shifts insofar as my clocked sense of Time was not as real as I had come to be in it. There were other subjective temporalities within my inner consciousness that Baby Ole guided me towards. Such subjective states also hinted towards an ontological playfulness which I further explored with Captain Duke. Using my adult agency to become receptive to new dimensions of creative reciprocity that were possible through the playfully constructed worlds of Captain Duke required climbing out of the network of meanings constituting my sense of 'world'. By tuning-in and making conscious efforts to synchronise with the alterity presented to me I could be in a 'kitchen' and simultaneously not in a 'kitchen'. In being and not being in a kitchen, my sense of temporality itself had to multiply. With children structurally positioned as 'pupils' and corresponding adults reduced to 'educators', the scope for creative reciprocity in adult-child relationships itself is unfortunately curbed. Nevertheless, I found that the scope is higher than instrumentalized, intersubjective educator-pupil positionings allow; positionings where the child is invariably the default addressee of pedagogy.

From a childist point of view any life-span regardless of age is an endless play of trying on new roles, appropriating various ways of being that are observed in others and performing them from diverse vantage points. Hierarchical compartmentalisations of sense-ability as the scope for creative reciprocity in the adult-child dynamic seem to bring about a sensory poverty in the adult. However, through more holistic phenomenological approaches that open up the scope of creative reciprocity in encountering the child as an educator could be a way to overcome the sensory poverty that especially comes with having 
over-appropriated the singular clock-sense of Time. Both adults and children could experience each other as teachers who reveal alternative ways of sensing and being in the world.

Temporal asymmetry between adults and children is the primary tension of the continuous present in terms of who is heard in the nowness of lived experiences. It is through this asymmetry that one can begin grasping the temporal otherness of the adult-child relationship. Seen particularly as part of the modern history where upscaled standardised Time and Money become inseparably coupled - a highly instrumentalized global education sector structurally produces childhoods filled with activities organised by adults and adultist structures. It is thus not only the child's but also, as a corollary, the adult's scope for exploring various temporalities that could be experienced outside socially 'real' set of singular, external clock-time rhythm which remains systematically restricted and ordered. This restriction initiates a sensory poverty extending into adulthood. A journey from butterflydom to caterpillardom.

The acknowledgement of temporal asymmetry and by extension temporal otherness is not intended, however, to condemn adults for oppressing or objectifying children. It is intended to take a curious and compassionate stance towards the adult self. Nevertheless, in taking this compassionate and curious stance towards the self (assuming the reader too is an adult), one cannot mollycoddle oneself out of facing the fact that it takes conscious effort on our part to minimise the asymmetry in order to learn to sense Time in its plurality.

Thereof, I that when it comes to the sensory education of temporalities, it seems that as an adult I have more to learn from, than teach infants and children. In a holistic phenomenological sense what prominently occurs to me here is:

Clocks interrupt Time. They don't constitute it. It is but one temporality, among several others that are intersubjectively fleeting in me. Several that I have yet to sense with (hos/bei) children.

Acknowledgements This project has been funded by the Equal Opportunities Funding and Chair for General Pedagogy, University of Bayreuth. Also, a special thanks to the Department of Education and Lifelong Learning - Norwegian University of Science and Technology, Thomas Hylland Eriksen, Aniket Jaaware, Marit Honerød Hoveid and Alice Pinheiro Walla for their support.

Funding Open Access funding enabled and organized by Projekt DEAL.

Data availability Data not available due to ethical restrictions (confidentiality and anonymity protection of participants).

\section{Declarations}

Conflict of interest The author declare that he/she has no conflict of interest.

Open Access This article is licensed under a Creative Commons Attribution 4.0 International License, which permits use, sharing, adaptation, distribution and reproduction in any medium or format, as long as you give appropriate credit to the original author(s) and the source, provide a link to the Creative Commons licence, and indicate if changes were made. The images or other third party material in this article are included in the article's Creative Commons licence, unless indicated otherwise in a credit line to the material. If material is not included in the article's Creative Commons licence and your intended use is not permitted by statutory regulation or exceeds the permitted use, you will need to obtain permission directly from the copyright holder. To view a copy of this licence, visit http://creativecommons.org/licenses/by/4.0/. 


\section{References}

Biswas, Tanu. 2017. Philosophieren mit Kindern über Grenzen hinweg - eine childistische Perspektive. Polylog 37: 89-102.

Biswas, Tanu. 2020. Little Things Matter Much: Childist Ideas for a Pedagogy of Philosophy in an Overheated World. Münich: BüroHimmelgrün.

Bahler, Brock. 2015. Merleau-Ponty on Children and Childhood. Childhood \& Philosophy 11: $203-221$.

Beauvais, Clémentine. 2018. Thinking the Adult-Child Relationship with Existentialism. In Reimagining Childhood Studies, ed. Spyros Spyrou, Rachel Rosen, and Daniel Thomas Cook, 57-74. London: Bloomsbury Academic.

Biesta, Gert, Noguera- Ramirez, and Carlos Ernesto. 2019. What is the Educational Task? Arousing the Desire for Wanting to Exist in the World in a Grown-Up Way. Pedagogia y Saberes 50: 63-74.

Bonnardel, Yves. 2015. La Domination Adulte. L'oppression des mineurs. Canejan: Myriadis.

Bøyum, Steinar. 2002. FilosofiogNaivitet. Idealtypiskesynpåfilosofiensforholdtildetbarnlige. Barn 2: 99-116.

Cassidy, Claire. 2017. Grown-Upness or Living Philosophically? Childhood \& Philosophy 13(28): 481-492.

Duane, Anna Mae, ed. 2013. The Children's Table: Childhood Studies and the Humanities. Athens, GA: University of Georgia Press.

Ennew, Judith. 1994. Time for Children or Time for Adults. In Childhood Matters-Social Theory, Practice and Politics, ed. Jens Qvortrup, Marjatta Bardy, Giovanni Sgritta, and Wintersberger Wintersberger, 125-143. Aldershot: Avebury.

Eriksen, Thomas Hylland. 2001. Tyranny of the Moment-Fast and Slow Time in the Information Age. London: Pluto Press.

Eriksen, Thomas Hylland. 2016. Overheating-An Anthropology of Accelerated Change. London: Pluto Press.

Flascher, Jack. 1978. Adultism. Adolescence 13(51): 517-523.

Gopnik, Allison. 2009. The Philosophical Baby: What Children's Minds Tell Us About Truth, Love \& the Meaning of Life. London: Random House.

Heidegger, Martin. 1972. Sein und Zeit. Tübingen: Max Niemeyer Verlag.

Heidegger, Martin. 1977. The Question Concerning Technology and other Essays, trans. William Lovitt. New York: Harper \& Row.

Heidegger, Martin. 2010. Being and Time. Albany: State University of New York Press.

Intergovernmental Panel on Climate Change (IPCC). 2018. Global warming of $1.5^{\circ} \mathrm{C}$. In An IPCC Special Report on the impacts of global warming of $1.5^{\circ} \mathrm{C}$ above pre-industrial levels and related global greenhouse gas emission pathways, in the context of strengthening the global response to the threat of climate change, sustainable development, and efforts to eradicate poverty. ed. V. Masson-Delmotte, P. Zhai, H. O. Pörtner, D. Roberts, J. Skea, P. R. Shukla et al. Geneva: World Meteorological Organization.

James, Allison, Chris Jenks, and Alan Prout. 1998. Theorizing Childhood. Cambridge: Polity Press.

Kant, Immanuel. 1904. The Educational Theory of Immanuel Kant, 4th ed. Philadelphia: JB Lippincott.

Murris, Karin, and Walter Kohan. 2020. Troubling Troubled School Time: Posthuman Multiple Temporalities. International Journal of Qualitative Studies in Education. https://doi.org/10.1080/09518398. 2020.1771461.

Kennedy, D., and W. Kohan. 2008. Aión, Kairós and Chrónos: Fragments of an Endless Conversation on Childhood, Philosophy and Education. Childhood \& Philosophy 4(8): 5-22.

Kohan, Walter Omar. 2011. Childhood, Education and Philosophy: Notes on Deterritorialization. Journal of Philosophy of Education 45(2): 339-357.

Kohan W.O. 2014. Celebrating Thirty Years of Philosophy for Children. In Philosophy and Childhood: Critical Perspectives and Affirmative Practices. New York: Palgrave Pivot. https://doi.org/10.1057/ 9781137469175_2.

Lippitz, W. 1983. The child's understanding of time. Phenomenology \& Pedagogy 2(3): 172-180.

Oswell, David. 2013. The Agency of Children - From Family to Global Human Rights. New York: Cambridge University Press.

Schapiro, Tamar. 2003. Childhood and Personhood. Arizona Law Review 45(3): 575-594.

Speier, Matthew. 1976. The adult ideological viewpoint in studies of childhood. In Rethinking Childhood - Perspectives on Development and Society, eds. Arlene Stolnick, 168-186. Boston: Little Brown \& Company.

Straume, Ingerid. 2019. What may we hope for? Education in times of climate change. Constellations, 1-13. https://doi.org/10.1111/1467-8675.12445. 
$\mathrm{Su}$, Hanno., and Su, Shia. 2019. Why solving intergenerational injustice through education does not work. On Education: Journal for Research and Debate, 2(4). https://doi.org/10.17899/on_ed.2019.4.3.

Tesar, Marek. 2016. Timing Childhoods: An Alternative Reading of Children's Development through Philosophy of Time, Temporality, Place and Space. Contemporary Issues in Early Childhood 17(4): 399_ 408. https://doi.org/10.1177/1463949116677924.

Thunberg, Greta. 2019. No One Is Too Small To Make a Difference. London: Penguin Books.

Wall, John. 2010. Ethics in Light of Childhood. Washington, DC: Georgetown University Press.

Wall, John. 2013. All the World's a Stage. Childhood and the Play of Being. In The Philosophy of Play, eds. Emily Ryall, Wendy Russell, and Malcom MacLean, 46-57. London: Routledge

Wall, John. 2019. From Childhood Studies to Childism. Children's Geographies. https://doi.org/10.1080/ 14733285.2019.1668912.

Welsh, Talia. 2013. The Child as Natural Phenomenologist. Primal and Primary Experience in MerleauPonty's Psychology. Evanston, IL: Northwestern University Press.

Publisher's Note Springer Nature remains neutral with regard to jurisdictional claims in published maps and institutional affiliations. 